\title{
Ontogenetic variations of thermal optimum for growth, and its implication on thermolabile sex determination in blue tilapia
}

\author{
E. Baras*†ף, A. Mpo’n’tcha†t, H. Driouch†§, Ch. Prignon† And \\ C. MÉlaRD $\dagger$ \\ * Department of Life Sciences, Ethology and Animal Psychology, University of Liège, \\ 10 Chemin de la Justice, B-4500 Tihange, Belgium; $\uparrow$ Aquaculture Research \\ and Education Centre, University of Liège, 10 Chemin de la Justice, B-4500 \\ Tihange, Belgium; $\ddagger$ Direction des Pêches, BP 383 Cotonou, Benin; §Institut \\ Agronomique et Vétérinaire Hassan II, Campus Horticole d'Agadir, BP 779 Agadir,
}

Morocco

(Received 31 December 2001, Accepted 30 July 2002)

\begin{abstract}
Knowledge of how the optimum temperature for growth $\left(T^{\circ}{ }_{\text {opt }}\right)$ varies during ontogeny, and how close it is to the temperatures that induce phenotypic masculinization is fundamental to the understanding of the evolution of thermolabile sex determinism (TSD) in fishes. In blue tilapia Oreochromis aureus, $T^{\circ}$ opt is $32.6^{\circ} \mathrm{C}$ at the start of exogenous feeding (10 mg fish) and it decreases by $c .1^{\circ} \mathrm{C}$ each time that the fish body mass increases by an order of magnitude. Temperatures $<35^{\circ} \mathrm{C}$ are not sufficient to induce complete phenotypic masculinization. Based on a multiple-regression model $\left(r^{2}=0.938\right)$ plotting growth against body mass and water temperature, genotypically female tilapia living at high temperatures during the thermosensitive period (21-28 days) and being reversed into phenotypic males would incur an initial growth disadvantage over fish living at $T^{\circ}{ }_{\text {opt}}$, but not over those living at slightly colder temperatures $\left(27-29^{\circ} \mathrm{C}\right)$. This initial disadvantage would be later compensated for by faster growth because of between-sex growth dimorphism to the detriment of phenotypic females. These arguments suggest that there is no definite pressure against the selection of TSD in blue tilapia and probably other Oreochromis spp.
\end{abstract}

(C) 2002 The Fisheries Society of the British Isles. Published by Elsevier Science Ltd. All rights reserved.

Key words: sex determination; temperature; evolution; survival; Oreochromis; Cichlidae.

\section{INTRODUCTION}

Temperature presumably is the most pervasive abiotic factor governing the growth of fishes (controlling factor, Fry, 1971), as it affects food intake, respiration, digestion and assimilation (Jobling, 1994, 1997; Kestemont \& Baras, 2001). The temperature at which fishes feeding maximally grow fastest (i.e. at which the scope for activity is greatest) is termed optimum temperature for growth $\left(T^{\circ}{ }^{\circ}\right)$, and it varies substantially between fish species. It is $c .12-17^{\circ} \mathrm{C}$ in salmonids, $20-22^{\circ} \mathrm{C}$ in temperate cyprinids, and $27-30^{\circ} \mathrm{C}$ in most tropical freshwater fish species (Wootton, 1990; Jobling, 1994; Kestemont \& Baras, 2001). Fish size and body mass are known to influence metabolism and growth (Brett, 1979; Jobling, 1983), essentially as a result of the allometric growth of

qAuthor to whom correspondence should be addressed. Tel.: +32 852741 56; fax: +32 85230592 ; email: E.Baras@ulg.ac.be 
exchange surfaces (e.g. gills and intestines) that govern anabolism, and volume (or mass) that governs catabolism (Pauly, 1981; Jobling, 1994). It is generally accepted that $T^{\circ}$ opt decreases during ontogeny, and changes of this nature have been illustrated in several fish species [sole Solea solea (L.), Fonds \& Saksena, 1977; common carp Cyprinus carpio L., Huisman et al., 1979; sharptooth catfish Clarias gariepinus (Burchell), Hogendoorn et al., 1983; tilapia Oreochromis mossambicus (Peters), Mironova, 1976; Nile tilapia Oreochromis niloticus L., Mélard, 1986; Salmo salar L., Koskela et al., 1997]. This has rarely been studied in their very early life stages.

Modelling the ontogenetic changes of $T^{\circ}$ opt is essential to the understanding of ecological and physiological constraints on fish growth, habitat selection and behavioural thermoregulation, as well as to the optimization of culture conditions. It is also of particular interest in gonochoristic fish species that share a thermolabile sex determination (TSD) mechanism, and produce progenies with variable sex ratios depending on ambient temperature during the thermosensitive period (Baroiller et al., 1999; Strüssmann \& Patino, 1999). In the majority of species examined to date, low and high temperatures favour the differentiation of female and male gonads, respectively [e.g. sea bass Dicentrarchus labrax (L.); Pavlidis et al., 2000; atherinids: Conover \& Kynard, 1981; Conover \& Heins, 1987a, b; Strüssmann et al., 1996a, b; callichthyids: Hostache et al., 1995; cobitids: Nomura et al., 1998; poeciliids: Schultz, 1993; Römer \& Beisenherz, 1996). In cichlids, only phenotypic masculinization at warm temperature has been reported (Baroiller et al., 1995, 1996a, b; Desprez \& Mélard, 1998; Baras et al., 2000, 2001) with the exception of feminization of genotypically male fishes at high temperature (Abucay et al., 1999). Temperatures at which masculinization is obtained $\left(36-37^{\circ} \mathrm{C}\right.$ in Nile tilapia; $34-35^{\circ} \mathrm{C}$ in blue tilapia Oreochromis aureus Steindachner) are much warmer than the $T^{\circ}$ opt of large juveniles and adults $\left(27-30^{\circ} \mathrm{C}\right.$; Philippart \& Ruwet, 1982; Mélard, 1986), but they are probably closer to the $T^{\circ}$ opt of early life stages. The question is how close? Within an ecological and evolutionary perspective, the smaller the difference between $T^{\circ}$ opt and masculinizing (or feminizing) temperatures during the thermosensitive period, the greater the chance that sexreversed fishes grow fast, escape predators and survive until the breeding stage, and the greater the probability that TSD be selected. Implicit in this assumption is the correspondence between $T^{\circ}$ opt and the final thermal preferendum (i.e. the temperature zone in a thermal gradient in which individuals of a given species ultimately congregate, irrespective of acclimatization temperature), but the two values often seem to coincide in fishes (Jobling, 1981; Wootton, 1990).

This study examined the ontogenetic variations of $T_{\text {opt }}^{\circ}$ in the blue tilapia, focusing on the early juvenile stage $(0 \cdot 01-3 \mathrm{~g})$ that encompasses the thermosensitive period in Oreochromis spp. (Baroiller et al., 1996a, 1999; Desprez \& Mélard, 1998; Baras et al., 2000, 2001). It aimed at (i) determining the proximity between $T^{\circ}$ opt and masculinizing temperature in fish of different ages or sizes, (ii) providing complementary data for the delimitation of the thermosensitive period, and (iii) quantifying the growth disadvantage incurred by fish exposed to masculinizing temperatures during this period over those exposed to $T^{\circ}$ opt . 


\section{MATERIAL AND METHODS}

\section{EXPERIMENTAL PROTOCOL}

Blue tilapia used in this study originated from the Aquaculture Station of Dor (Israel), and had been reared and bred for 15 years in the Aquaculture Station of the University of Liège in Tihange. Fertilized eggs were obtained from mouthbrooding females stocked in a $4 \mathrm{~m}^{2}$ tank together with a single male, and inspected at 1 week intervals. On each day when eggs were collected, there was a single mouthbrooding female, and the progeny was deemed to contain full siblings. Eggs were gently removed from the mouth of the female, and were incubated in $0.751 \mathrm{Zug}$ jars at $27 \pm 1^{\circ} \mathrm{C}$ (mean \pm range) until hatching. Embryos were then placed into a 501 aquarium in an indoor recirculating system at $27 \cdot 5 \pm 0 \cdot 5^{\circ} \mathrm{C}$ until yolk sac absorption and start of exogenous feeding. Hereafter, the first day of exogenous feeding will be referred to as day 1. Progenies were subdivided into 10 groups containing identical numbers of siblings, which were stocked in 501 aquaria and exposed to different thermal regimes $\left(27,29,31,33\right.$ and $35^{\circ} \mathrm{C}$; two replications per treatment) over 3 consecutive weeks. The relationships between growth, temperature, age and body mass of juvenile blue tilapia were investigated during two consecutive experiments conducted in identical conditions, except for the age and size at exposure to different thermal regimes. During the first experiment, thermal exposure started on day 1 and extended until day 21. During the second experiment, the progeny were held altogether at $27 \cdot 3^{\circ} \mathrm{C}$ until day 14 , then subdivided into 10 groups that were exposed to different water temperatures from day 15 to 35 .

Each aquarium was equipped with an individual heating system (Biotherm 2000 thermostat and $300 \mathrm{~W}$ heating resistance) permitting maintenance of water temperatures to experimental values, to the nearest $0 \cdot 2^{\circ} \mathrm{C}$. The transition from $27^{\circ} \mathrm{C}$ to the rearing temperature was achieved within $<3 \mathrm{~h}$. Such fast transitions were deemed not to be detrimental to juvenile blue tilapia, in view of recent experiments, in which juvenile blue tilapia were exposed to temperatures fluctuating between $27^{\circ} \mathrm{C}$ during the night and $35^{\circ} \mathrm{C}$ during the day over 4 consecutive weeks, and showed no growth deficit or increased mortality (Baras et al., 2000). No temperature $>35^{\circ} \mathrm{C}$ was assayed here, because the exposure of juveniles to $34-35^{\circ} \mathrm{C}$ over 4 weeks is sufficient for phenotypic sex reversal in blue tilapia (Desprez \& Mélard, 1998; Baras et al., 2000). Also, it was important not to expose juvenile blue tilapia to temperatures close to the upper incipient lethal temperature (38-39 ${ }^{\circ} \mathrm{C}$ for the strain used here; C. Mélard, D. Desprez and E. Baras, unpubl. obs.). This might have resulted in additional, and possibly size- or sex-dependent, mortality that could have biased the interpretation of the results (Baras et al., 2001). Similarly, no temperature $<27^{\circ} \mathrm{C}$ was evaluated here, because the optimum temperature of adults is $c$. $28^{\circ} \mathrm{C}$ (Philippart \& Ruwet, 1982), and temperatures $\leq 27-28^{\circ} \mathrm{C}$ have no masculinizing effect on blue tilapia (Desprez \& Mélard, 1998; Baras et al., 2000).

Photoperiod was $12 \mathrm{~L}: 12 \mathrm{D}$ throughout both experiments, with light intensities of $70 \pm 5$, and $0 \cdot 01 \pm 0 \cdot 001 \mathrm{~lx}$ (mean \pm range) during periods of light and darkness, respectively. Fish were fed with formulated feed (Nippai Sea Bream; fat: 8.5\%; proteins: 55\%; then Biomar Ecostart; fat: $18 \%$; proteins: $50 \%$ ) that was distributed by hand six times a day during the hours of light. Daily food rations were increased progressively during the experiment so fish were fed slightly in excess throughout. Provision of food in slight excess was a prerequisite to the calculation of $T^{\circ}$ opt, as restricted feeding has a marked influence on its determination (Elliott, 1975a, b; Kitchell et al., 1977; Hogendoorn et al., 1983; Jobling, 1994). In each experiment, all groups of fish were initially given the same amount of food, then the ration was slightly reduced (but still in excess) in groups showing slower growth to avoid pollution by uneaten feed. Faeces and uneaten feed were siphoned twice a day. During the entire treatment, water renewal rate was adjusted to maintain sufficient water quality $\left(<0.2 \mathrm{mg} \mathrm{NO}_{2}^{-} 1^{-1} ;<0.4 \mathrm{mg} \mathrm{NH}_{3} 1^{-1}\right)$, and an air diffuser permitted maintenance of oxygen concentration near saturation.

Aquaria were searched for dead fish, and water temperature was measured at least twice a day. On days 8, 15 and 22 (experiment 1), and 22, 29 and 36 (experiment 2), fish were counted and biomass was measured to the nearest $0 \cdot 1 \mathrm{~g}$. Twenty fish were randomly sampled in each group, anaesthetized with 2-phenoxy-ethanol $\left(0.4 \mathrm{ml}^{-1}\right)$ and weighed 
individually (nearest $0.001 \mathrm{~g}$ ) to measure the effect of the thermal regime on size heterogeneity [expressed as the coefficient of variation $(\mathrm{CV}, \%)$ of the mean body mass]. Missing fish were deemed to have succumbed to complete cannibalism.

After 3 weeks of exposure to dedicated thermal regimes, water temperature was returned to $27 \pm 1^{\circ} \mathrm{C}$ within $4 \mathrm{~h}$, and tilapia were reared at this non-masculinizing temperature until they reached the minimum size for sexing. Assuming that fish mortality in the treated or control groups can be sex-dependent, the masculinizing efficiency can only be measured within a certain range, which is proportional to fish mortality (Baras et al., 2001). It is thus important that fish be sexed at the youngest possible age for providing accurate estimates of masculinizing effects. By using the aceto-carmine squash method (Guerrero \& Shelton, 1974), the practical feasibility limit for readily extracting the gonads of young blue tilapia is $c .130 \mathrm{mg}$. It is recommended, however, that fish be sexed at a larger size, ideally after the end of the thermosensitive period (thought to range from 21 to 28 days after the start of exogenous feeding, by analogy with O. niloticus; Baroiller et al., 1996a).

\section{MODELLING ONTOGENETIC VARIATIONS OF OPTIMUM TEMPERATURE FOR GROWTH}

In all experiments, growth is expressed as the specific growth rate $\left(G, \% \mathrm{day}^{-1}\right)$, which is calculated as: $G=100\left(\ln \left(M_{2}\right)-\ln \left(M_{1}\right)\right)\left(t_{2}-t_{1}\right)^{-1}$, where $M_{2}$ and $M_{1}$ are the mean body masses at times $t_{2}$ and $t_{1}$, respectively.

The optimum temperature for growth $\left(T_{\text {opt }}^{\circ}\right)$ in fish of different ages is conventionally obtained by (i) plotting, for each age class, $G$ against $T^{\circ}$, (ii) modelling the relationship between the two variables by a polynomial model, and (iii) determining $T^{\circ}{ }_{\text {opt }}$ by differentiation of the polynomial model. The ontogenetic variation of $T^{\circ}{ }_{\text {opt }}$ is then given by plotting $T^{\circ}{ }_{\text {opt }}$ against age. Growth rate is negatively correlated with body mass $(M$; power relationship; Brett, 1979; Jobling, 1983), so this procedure is valid only when using fish of equivalent $M$ at the start of each growth experiment, and this was not the case here, except for the first week of each experiment. While using the experimental design applied here, the simplest alternative for describing the ontogenetic variations of $T_{\text {opt }}^{\circ}$, consists in (i) modelling the power relationships between $G$ and $M$ for each of the five temperatures assayed, (ii) plotting modelled $G$ against $T^{\circ}$ for a dedicated $M$ and calculating $T^{\circ}{ }_{\text {opt }}$, as above, and (iii) repeating this calculation for several $M$ within the range evaluated. This procedure is not fully satisfactory either, as it overlooks discrepancies between the thermal regimes applied during successive weeks or during different experiments. Additionally, this calculation relies on values that are produced by different mathematical models with presumably different $r^{2}$ values, and this can result in variable inaccuracy for different combinations of temperature and body mass. This also applies to the first procedure.

A more robust alternative is the elaboration of a multiple regression model of growth against body mass and temperature, which permits the calculation of $T^{\circ}$ opt in fish of different $M$ on a single and consistent basis. Intuitively, it can be perceived that the relationships between $G$ and $T^{\circ}$ for fish of increasing $M$ are a series of polynomials of decreasing magnitude (along $G$ ) and amplitude (along $T^{\circ}$ ). As the relationship between $G$ and $M$ at a dedicated temperature follows a power law, the decrease in magnitude of the polynomial models plotting $G$ against $T^{\circ}$ is assumed to follow a law of similar form, thus giving conceptual model (1):

$$
\log (n+G)=a+b T^{\circ}\left[\text { or } \log \left(T^{\circ}\right)\right]+c T^{\circ \mathrm{m}}\left[\text { or } \log \left(T^{\circ \mathrm{m}}\right)\right]+d \log (M)
$$

where $G$ is the specific growth rate $\left(\%\right.$ day $\left.^{-1}\right), T^{\circ}$ is the ambient temperature $\left({ }^{\circ} \mathrm{C}\right)$ and $M$ is the body mass $(\mathrm{mg}), n$ is a positive coefficient taking into account the possibility that fish show negative growth (mass loss) when exposed to a particular temperature, and $\mathrm{m}$ is $>1$. Because the amplitudes of the polynomial relationships between $G$ and $T^{\circ}$ are also likely to be influenced by body mass, a fourth interaction variable [i.e. $T^{\mathrm{op}} \times \log (M)$ or $\left.\log \left(T^{\circ p}\right) \times \log (M)\right]$ is needed, thus giving: 
$\log (n+G)=a+b T^{\circ}\left[\right.$ or $\left.b \log \left(T^{\circ}\right)\right]+c T^{\circ \mathrm{m}}\left[\right.$ or $\left.c \log \left(T^{\circ \mathrm{m}}\right)\right]+d \log (M)+$

$$
e T^{\mathrm{op}} \log (M)\left[\text { or } e \log \left(T^{\circ \mathrm{p}}\right) \log (M)\right]
$$

where $\mathrm{p}$ is a positive exponent, the value of which is proportional to how steep is the decrease of $T^{\circ}$ opt in fish of increasing body mass.

In order to determine which predictor variables and coefficients (e.g. $T^{\circ}$ or $\log T^{\circ}, \mathrm{m}=1$ or $\mathrm{m}=2$ ) gave the best fit for $G$, a stepwise multiple-regression analysis was performed on the data set ( 6 weeks $\times$ five temperatures $\times$ two replications). The resulting model was then used to calculate $G_{\max }$ and associated $T^{\circ}$ opt for fish of different $M$ within the range evaluated. Finally, the relationship between $T^{\circ}{ }_{\text {opt }}$ and $M$ was calculated.

The only methodological constraints pertaining to this model are the consistency of food rations in the different experiments, and of the periods over which growth is measured. These constraints were respected here, as fish growth was always measured at 1 week intervals, and fish were fed slightly in excess throughout. An additional constraint relates to fish mortality, which can be size-dependent, and bias the calculation of $G$. Therefore, data from groups where more than five fish died over a single week were not taken into account in the analysis.

\section{STATISTICS}

Contingency table analyses and Fisher exact tests were used to compare the rates of mortality and sex ratios of progenies reared under different thermal regimes, and to test for differences between the sex ratios of controls $\left(27^{\circ} \mathrm{C}\right)$ and a balanced $(1: 1)$ sex ratio. For each rearing week, body masses of fish reared at different temperatures were compared with one-way ANOVA and Scheffe $F$-tests comparison of means. Null hypotheses were rejected at $P<0 \cdot 05$.

\section{RESULTS}

\section{EFFECT OF WATER TEMPERATURE ON MORTALITY AND GROWTH}

A technical failure in the heating systems caused a high initial mortality in both groups of fish reared at $29^{\circ} \mathrm{C}$ in the first experiment. These were excluded from the analysis. Except for these groups, survival was extremely high (93.6-100.0\%) during the first experiment, and did not differ between treatments (Table I). During the second experiment, survival was significantly lower at $27-31^{\circ} \mathrm{C}$ than at higher temperatures $(78 \cdot 8-91 \cdot 3 v .97 \cdot 5 \%)$, essentially because of cannibalism, which was probably promoted by greater initial size heterogeneity (Fig. 1).

Fish reared at c. $33^{\circ} \mathrm{C}$ [Fig. 1(d)] achieved the fastest growth $\left(G_{\max }\right)$ over the first 3 weeks of exogenous feeding (experiment 1). Taking into account the small discrepancies between initial body masses in the second experiment, $G_{\max }$ over the third, fourth and fifth weeks of exogenous feeding was obtained at $c .31^{\circ} \mathrm{C}$ [Fig. 1(h)]. In both experiments, differences between $G_{\max }$ and growth at $35^{\circ} \mathrm{C}$ were low after 1 rearing week, and increased during the experiment (Fig. 1). Conversely, differences between $G_{\max }$ and growth at lower temperatures (27$29^{\circ} \mathrm{C}$ ) were high after 1 rearing week, and decreased later. Nevertheless, fish reared at $27^{\circ} \mathrm{C}$ were always smaller than those reared at $35^{\circ} \mathrm{C}$ at the end of both experiments. Temperatures that produced the fastest growth also resulted in the lowest size heterogeneity $\left[33^{\circ} \mathrm{C}\right.$ in experiment 1 ; Fig. 1(c)] or almost lowest size heterogeneity $\left(31\right.$ and $33^{\circ} \mathrm{C}$ in experiment 2; Fig. 1(g)]. Based on the CV of mean body mass, fish reared at $31-33^{\circ} \mathrm{C}$ were always more homogenous in size than those reared at lower temperatures. 


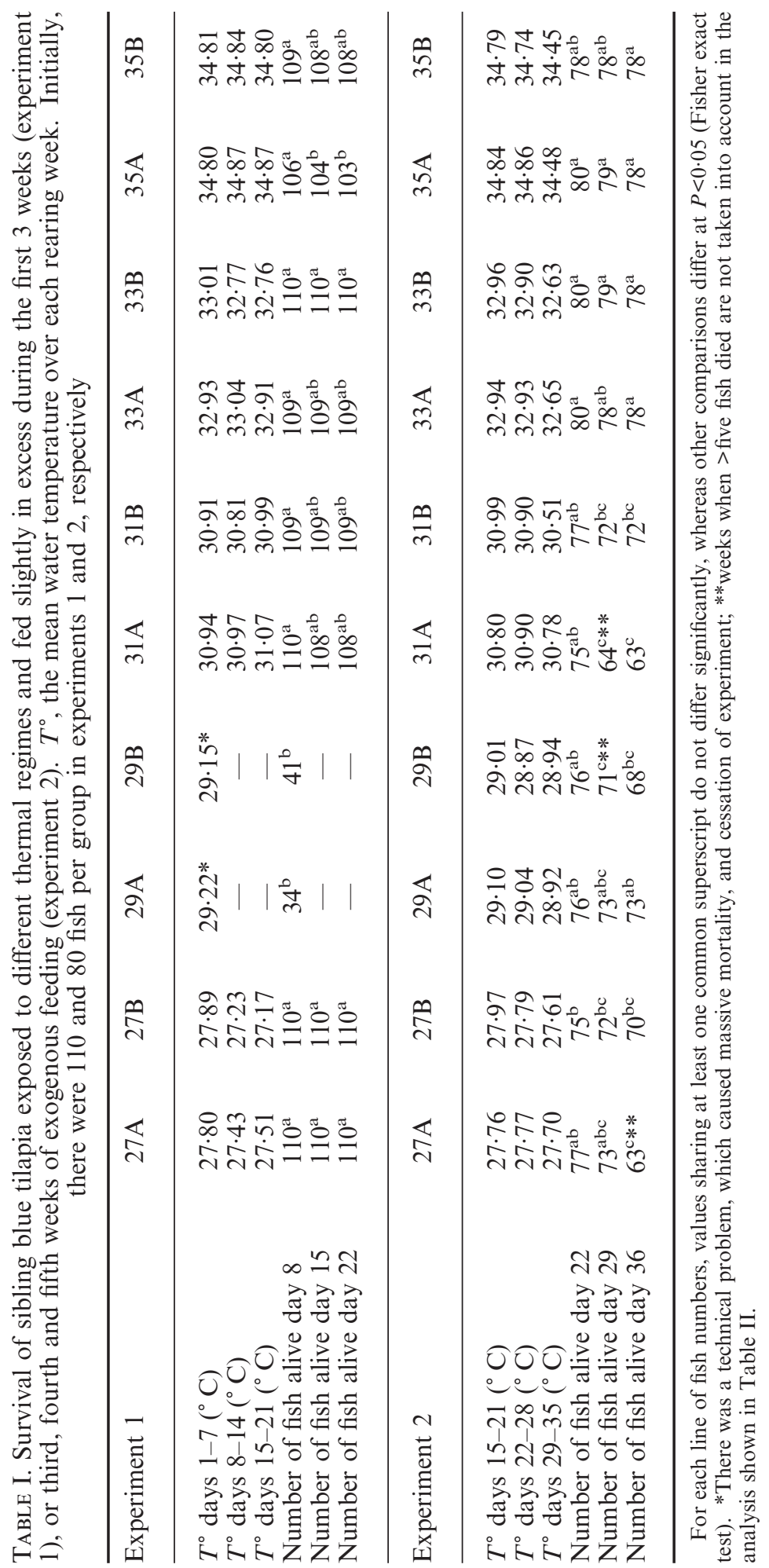


The stepwise multiple-regression analysis generated a four-component model accounting for $93.8 \%$ of the variation of $G$ (Table II; Fig. 2(a)]. The ontogenetic variation of $T^{\circ}{ }^{\circ}$, , as predicted by this general model, follows a negative power relationship [Fig. 2(b)], decreasing from $32 \cdot 6^{\circ} \mathrm{C}$ in $10 \mathrm{mg}$ juveniles, down to $30 \cdot 1^{\circ} \mathrm{C}$ in $3 \mathrm{~g}$ juveniles.

\section{EFFECT ON THERMAL REGIME ON PHENOTYPIC SEX}

Examinations of gonads of blue tilapia from experiment 1 on day 25 indicated that the exposure to $27^{\circ} \mathrm{C}$ over the first 3 weeks of exogenous feeding had produced a balanced sex ratio, and no intersex fish (Table III). Exposure to temperatures $>27^{\circ} \mathrm{C}$ produced significantly higher proportions of males only in the groups reared at $35^{\circ} \mathrm{C}(84-94 \%)$. Exposure to temperatures $\geq 31^{\circ} \mathrm{C}$, however, resulted in lower proportions of fish with exclusively female tissue in their gonads $\left(35,18\right.$ and $0 \%$ at 31,33 and $35^{\circ} \mathrm{C}$, respectively), and presence of intersex fish (13, 23 and 11\%, respectively). The gonads of intersex individuals in the 31 and $33^{\circ} \mathrm{C}$ treatments contained essentially female tissue, whereas those of intersex fish in the $35^{\circ} \mathrm{C}$ treatment were dominated either by male or female tissues, or contained approximately equivalent proportions of male and female tissues.

Analyses of sex ratios in the groups reared at $c .27^{\circ} \mathrm{C}$ throughout the second experiment revealed a strongly skewed sex ratio $(\hat{0}: q=1 \cdot 00: 0 \cdot 05)$, making it impossible to evaluate the effect of thermal regime during the third, fourth and fifth weeks of exogenous feeding on the phenotypic sex of blue tilapia. Nevertheless, sexing soon after the thermal treatments ended revealed intersex fish in all groups reared at $\geq 29^{\circ} \mathrm{C}$ (Table III), supporting the idea that temperatures as low as $29^{\circ} \mathrm{C}$ may have some masculinizing potential when applied during this ontogenetic interval.

\section{DISCUSSION}

Within an evolutionary perspective, thermolabile sex determinism (TSD) could only have been selected if it had provided more benefits than drawbacks to individuals or progenies sharing this mechanism. Advantages and drawbacks at the individual, population and species level, as they relate to rates of per capita increase and operational sex ratios, have been debated in previous articles (atherinids: Conover, 1984; Warner, 1988; cichlids; Baras et al., 2000, 2001). Implicit in this debate is that thermosensible and non-thermosensible progenies have equivalent chances of reaching sexual maturity and relaying their genes to the next generation, and thus that survival and growth are not excessively jeopardized by the exposure to a masculinizing temperature $\left(T^{\circ}{ }_{\text {masc }}\right)$ during the thermosensitive period (TP).

As regards the determination of $T^{\circ}$ masc and TP, this study provided further evidence that $35^{\circ} \mathrm{C}$ has a strong masculinizing potential, even when applied exclusively over the first 3 weeks of exogenous feeding. The proportion of males, however, was slightly lower in the present study than when the masculinizing temperature was applied over 4 weeks (Desprez \& Mélard, 1998; Baras et al., 2000), and intersex fish with a predominance of female tissue in their gonads were observed. In the light of previous studies using hormonal (Pandian \& 
Sheela, 1995) or thermal sex reversal treatments in tilapias (Baras et al., 2000), these intersex individuals can be regarded as genotypically female individuals, the gonads of which partly developed into male tissue. The fate of intersex blue tilapia if still alive at adulthood is uncertain, but there is some evidence that they
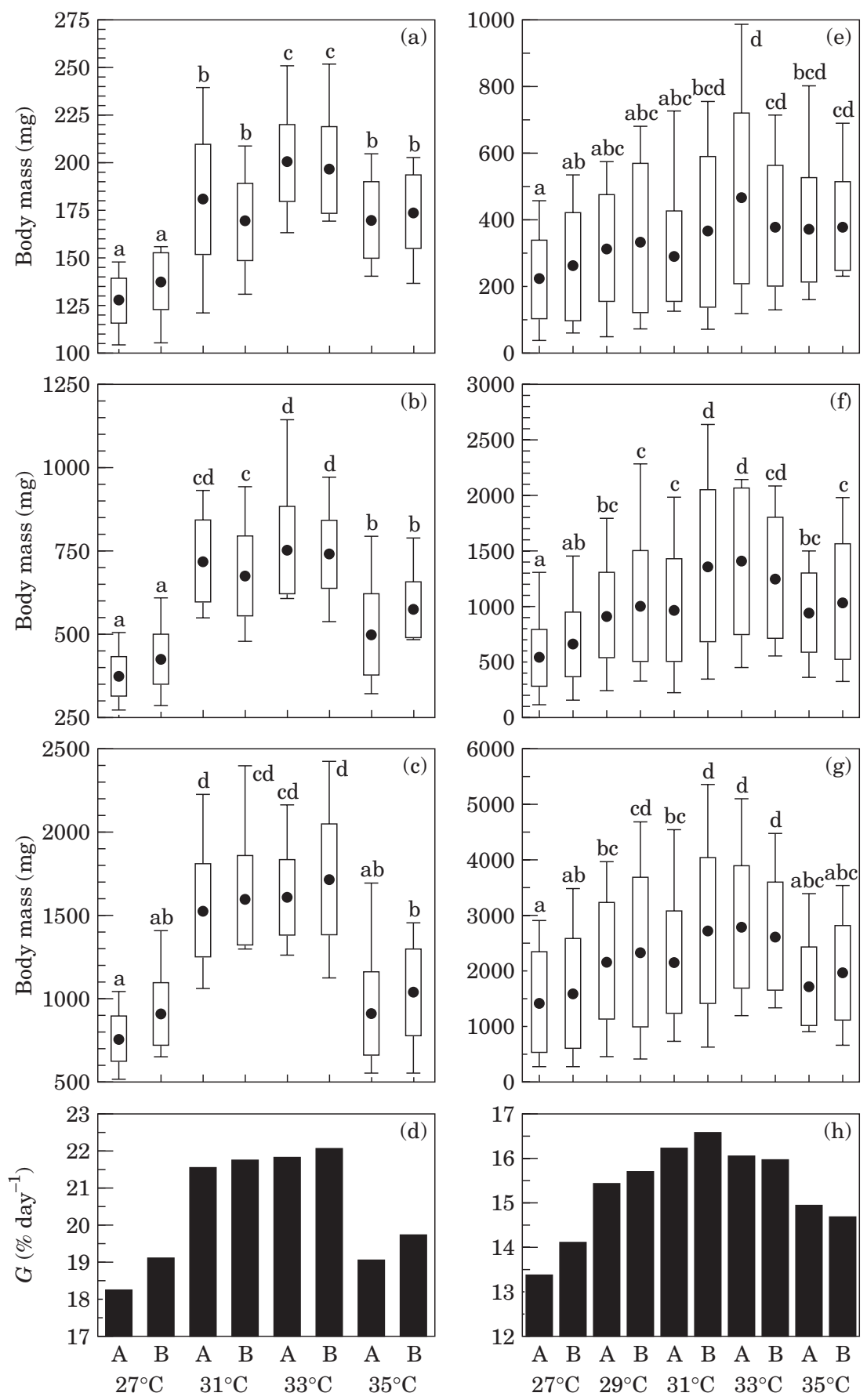
TABLE II. Multiple regression model of growth $\left(G, \%\right.$ day $\left.^{-1}\right)$ and body mass $(\mathrm{M}, \mathrm{mg})$ and ambient temperature $\left(T^{\circ} \mathrm{C}\right)$ in juvenile sibling blue tilapia fed in excess with formulated feed. Predictor variables are presented in order of entrance in a stepwise multiple-regression analysis. Growth is calculated over 1 week, and $M$ is the body mass at the start of the week

\begin{tabular}{lrrrr}
\hline Dependent variable: $\log (1+G)$ & \multicolumn{3}{c}{$F_{3,47}=173 \cdot 53$, d.f. $=50, P<0 \cdot 0001, r^{2}=0 \cdot 938$} \\
Predictor variables & Coefficient & S.E. & \multicolumn{1}{c}{$P$} \\
& & & $-6 \cdot 12$ & $<0 \cdot 0001$ \\
Intercept & $-78 \cdot 2911$ & $12 \cdot 7933$ & $2 \cdot 02$ & $0 \cdot 0494$ \\
$\log M$ & $0 \cdot 4655$ & $0 \cdot 2306$ & $6 \cdot 11$ & $<0 \cdot 0001$ \\
$\log T^{\circ}$ & $104 \cdot 9699$ & $17 \cdot 1768$ & $-5 \cdot 95$ & $<0 \cdot 0001$ \\
$\left(\log T^{\circ}\right)^{2}$ & $-34 \cdot 3378$ & $5 \cdot 7706$ & $-3 \cdot 19$ & $0 \cdot 0026$ \\
{$\left[\log M^{\circ} \times\left(\log T^{\circ}\right)^{2}\right]$} & $-0 \cdot 3271$ & $0 \cdot 1025$ & & \\
\hline
\end{tabular}
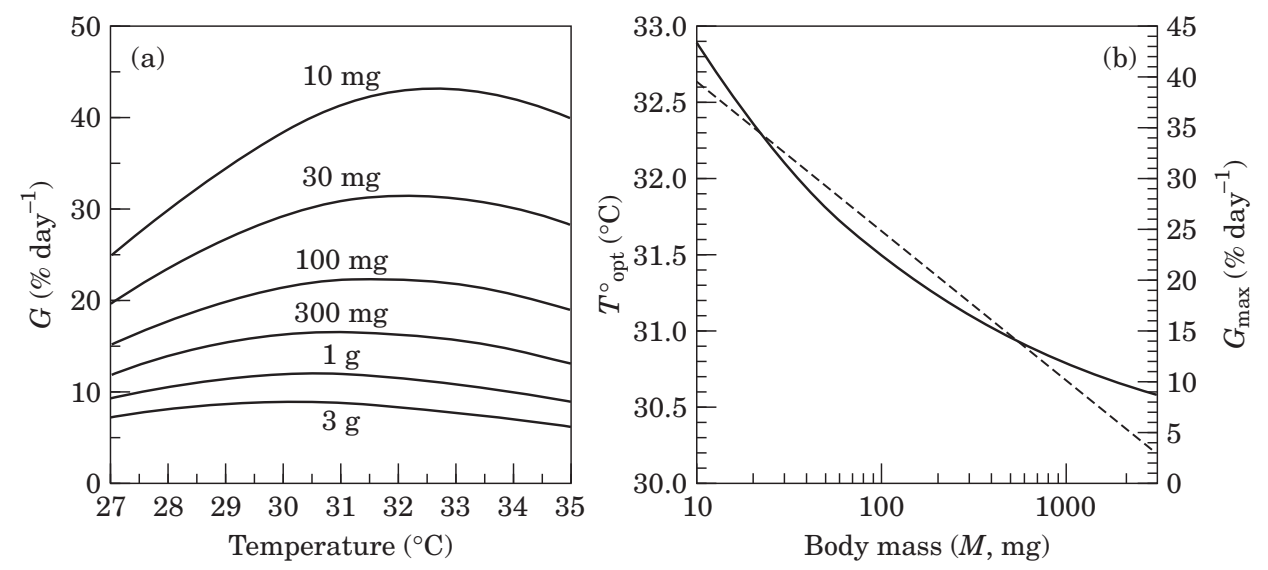

FIG. 2. (a) Growth of juvenile blue tilapia, depending on body mass and rearing temperature, as predicted by the multiple-regression model in Table II. (b) Ontogenetic variations of $G_{\max }$ ($\left.G_{\max }=81 \cdot 302 M^{-0.28237}\right)$ and $T^{\circ}{ }_{\text {opt }}\left(---, T^{\circ}{ }_{\text {opt }}=33 \cdot 664 M^{-0.01363}\right)$ deduced from this model.

only become males when the proportion of male tissue in their gonads largely exceeds that of female tissue (Baras et al., 2000; J.-F. Baroiller, pers. comm). Hence it is suggested that the end of the thermosensitive period in this species lies between 21 and 28 days after yolk sac absorption, (mean body mass of $1.200 \mathrm{mg}$ for fish feeding maximally, as estimated from this and previous experiments). Temperatures $<35^{\circ} \mathrm{C}$ seemingly had some masculinizing potential too, since

FIG. 1. Growth of juvenile sibling blue tilapia exposed to different thermal regimes and fed in excess during the first 3 weeks [experiment 1; (a)-(d)], or third, fourth and fifth weeks of exogenous feeding [experiment 2; (e)-(h)]. (a)-(c) and (e)-(g), body masses of fish at the end of each rearing week at the designated temperature. Mean body mass $(\bullet) \pm 1$ S.D. $(\square)$, and the entire size range (-) are given. (d) and (h), overall growth rates over 3 weeks. Survival rates and thermal regimes as in Table I. Mean initial body masses, experiment 1: 16.5-16.8 mg (homogeneous); experiment 2: $27 \mathrm{~A}, 86.6 \mathrm{mg} ; 27 \mathrm{~B}, 82.1 \mathrm{mg} ; 29 \mathrm{~A}, 84.8 \mathrm{mg} ; 29 \mathrm{~B}, 87.0 \mathrm{mg} ; 31 \mathrm{~A}, 71.9 \mathrm{mg} ; 31 \mathrm{~B}, 84.2 \mathrm{mg} ; 33 \mathrm{~A}$, $96.2 \mathrm{mg} ; 33 \mathrm{~B}, 92.5 \mathrm{mg} ; 35 \mathrm{~A}, 74.8 \mathrm{mg} ; 35 \mathrm{~B}, 91.1 \mathrm{mg}$. For each graph, values sharing at least one common superscript do not differ significantly, whereas other comparisons differ at $P<0 \cdot 05$ (ANOVA and Scheffe $F$-tests). ANOVA (a): $F_{7,152}=43 \cdot 1, P<0 \cdot 0001$; ANOVA (b): $F_{7,152}=40 \cdot 0$, $P<0.0001$; ANOVA (c): $F_{7,152}=47 \cdot 3, P<0 \cdot 0001$. ANOVA (e): $F_{9,190}=3 \cdot 0, P=0 \cdot 0024$; ANOVA (f): $F_{9,190}=6 \cdot 8, P<0 \cdot 0001 ;$ ANOVA $(\mathrm{g}): F_{9,190}=4 \cdot 6, P<0 \cdot 0001$. 


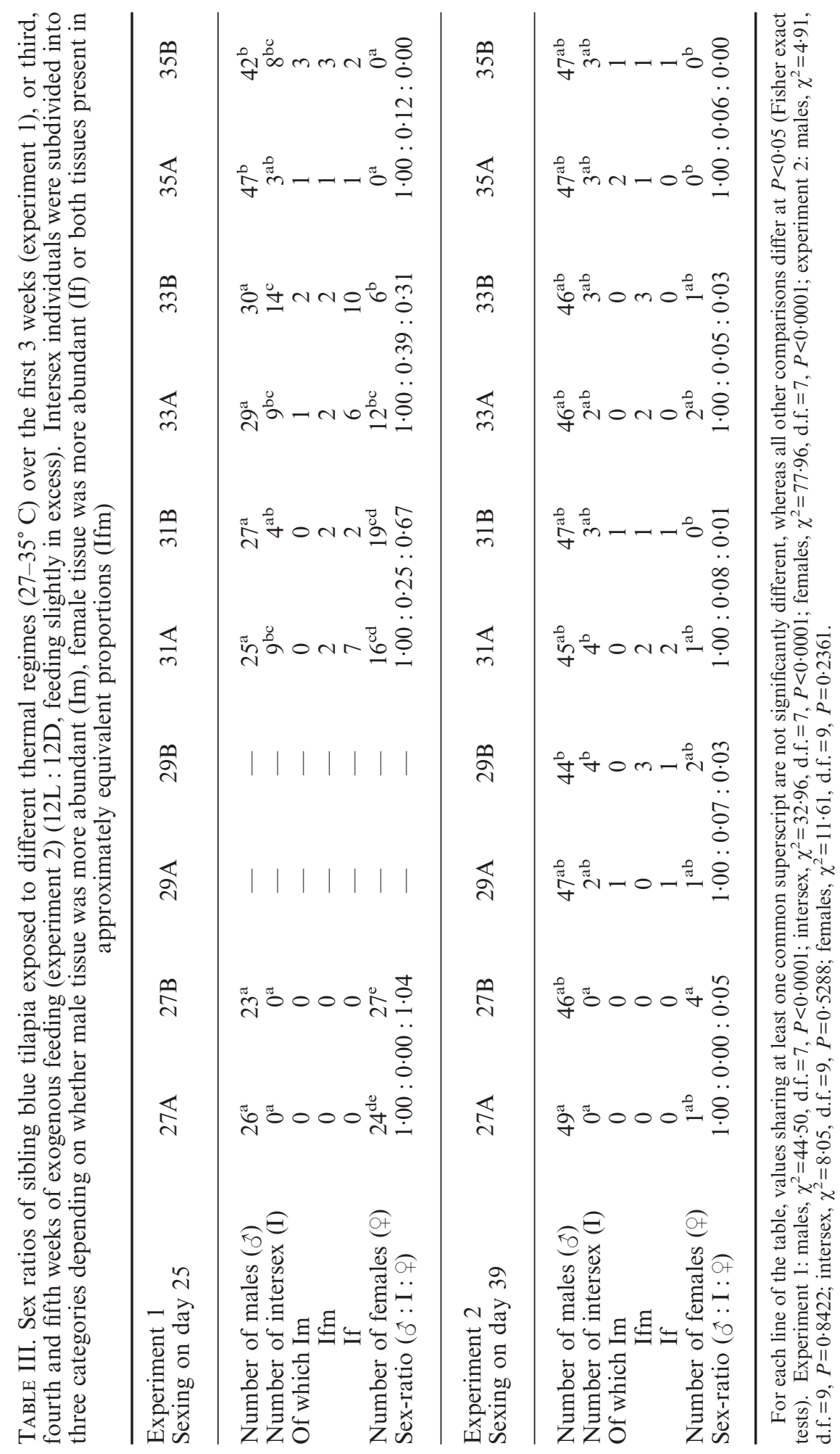


intersex individuals were observed at rearing temperatures as low as $29^{\circ} \mathrm{C}$. The proportions of males in these treatments, however, never differed from those in the control groups at $27-28^{\circ} \mathrm{C}$, and the gonads of intersex fish contained essentially female tissue, thereby suggesting that these temperatures were not warm enough for sex reversal, and that a minimum of $35^{\circ} \mathrm{C}$ was needed for masculinization.

Further information on the beginning of the thermosensitive period was expected from the second experiment, but this was made impossible by the strongly skewed sex ratio in the control groups reared at $27^{\circ} \mathrm{C}$. It cannot be excluded that the dam was a $\mathrm{ZZ}$ pseudofemale, although this is unlikely since the ZZ pseudofemales were held in separate rearing units. Desprez (1998) revealed that some $\mathrm{ZW}$ female blue tilapia could produce almost monosex male progenies at $27-28^{\circ} \mathrm{C}$, and invoked secondary determinants of phenotypic sex other than temperature. Similar cases have been reported in cichlids and other taxa, either in an environment-independent (Baroiller et al., 1996c; Baroiller et al., 1999) or environment-dependent context (e.g. influence of stocking density, Francis, 1984; influence of pH, Rubin, 1985; Römer \& Beisenherz, 1996). Female Oreochromis spp. continue mouthbrooding behaviour after their young have absorbed their yolk sac (Ruwet, 1968). Temperatures that can masculinize tilapias are much warmer than those preferred by large females, and it is thus unlikely that the first days following yolk absorption are a necessary part of the thermosensitive period. This interpretation is supported by recent experiments in which groups of sibling Nile tilapia first reared at $27^{\circ} \mathrm{C}$ until up to 11 days after yolk absorption, then reared at $37^{\circ} \mathrm{C}$ over 4 weeks, all gave monosex male populations (E. Baras, Ch. Prignon, X. Tian, H. Driouch \& C. Mélard, unpubl. data). Experimental evidence, however, is lacking for blue tilapia, and it is assumed that phenotypic sex reversal requires blue tilapia to be exposed to $35^{\circ} \mathrm{C}$ from the start of exogenous feeding.

This study indicated that the exposure to $T^{\circ}$ masc was not detrimental, since the survival rate of blue tilapia at $35^{\circ} \mathrm{C}$ was equivalent to (experiment 1) or higher than among groups exposed to lower temperatures (experiment 2). Previous studies also provided evidence that survival of blue tilapia after 4 weeks at $35^{\circ} \mathrm{C}$ was similar to, or better than at 27-28 ${ }^{\circ} \mathrm{C}$ (Desprez \& Mélard, 1998; Baras et al., 2000). As regards growth, $T^{\circ}$ opt was found to be lower than the masculinizing temperature during the entire thermosensitive period, and was modelled to decrease by $c .1^{\circ} \mathrm{C}$ as the fish body mass increased by an order of magnitude. Extrapolating beyond the body mass range examined here gives $T^{\circ}{ }_{\text {opt }}$ estimates of $29 \cdot 1-28 \cdot 2^{\circ} \mathrm{C}$ for blue tilapias of $50-500 \mathrm{~g}$. This is consistent with the range $\left(27-30^{\circ} \mathrm{C}\right)$ proposed by Philippart \& Ruwet (1982) for large juveniles and adults of this species, and with those documented by Ruyung \& Yushu (1982) and Mélard (1986) for other Oreochromis spp. The rate of decrease of $T^{\circ}{ }_{\text {opt }}$ in fish of increasing size is also in good correspondence with those documented in larger juveniles of tropical fish species (sharptooth catfish, Hogendoorn et al., 1983; Nile tilapia, Mélard, 1986).

Despite its consistency and high statistical resolution $\left(r^{2}=0.938\right)$, it is likely that the model shown in Table II cannot be transposed to any set of environmental conditions. Jobling (1994) reported the example of 0 year group hybrid bass [Morone saxatilis (Walbaum) $\times M$. chrysops (Rafinesque)], the $T^{\circ}{ }_{\mathrm{opt}}$ of 
which was $27 \cdot 9^{\circ} \mathrm{C}$ under increasing day length, but only $25 \cdot 1^{\circ} \mathrm{C}$ under decreasing day length. $T^{\circ}$ opt is also likely to decrease with decreasing oxygen concentration, since an increase in metabolism with increasing temperature can only be satisfied under high oxygen concentration. Buentello et al. (2000) found that the growth of $15 \mathrm{~g}$ juveniles of channel catfish Ictalurus punctatus Rafinesque peaked at $27 \cdot 1^{\circ} \mathrm{C}$ with oxygen maintained to saturation, whereas it reached a plateau at $22.8^{\circ} \mathrm{C}$ at $30 \%$ saturation. There may also be more or less substantial variations of $T^{\circ}{ }_{\text {opt }}$ depending on geographical origin or strain (e.g. $16-19^{\circ} \mathrm{C}$ and $15 \cdot 6^{\circ} \mathrm{C}$ in Atlantic and Baltic populations of S. salar, respectively; Farmer et al., 1983; Koskela et al., 1997). The influence of oxygen concentration is probably minimal here, as all experiments were conducted near saturation, and it is unlikely that $T^{\circ}$ opt be strongly underestimated. Photoperiodic influences are unlikely either, in view of the limited variations of day length in tropical regions. Variations of $T^{\circ}{ }_{\text {opt }}$ between strains of blue tilapia are unknown, but possible in view of the broad geographical distribution of this species. Nevertheless, this study was made on the same strain upon which all experiments on TSD were conducted, and the model remains consistent for calculations with this particular strain. The model was calculated from mean growth rates, and some individuals did much better than predicted. Whether these fish are just fast growers, or fish with different $T^{\circ}$ opt remains to be determined.

Based on the growth model, young blue tilapia exposed to $35^{\circ} \mathrm{C}$ over 4 weeks (the maximum extension of the thermosensitive period) would reach c. 55\% of the body mass of siblings exposed to $T^{\circ}{ }_{\text {opt }}$ during this interval [corresponding difference in total body length $\left(L_{\mathrm{T}}\right)$ and swimming capacity: c. 17\%; Fig. 3]. Metabolism is proportional to temperature, and food availability is a limiting factor in natural environments, so the actual growth deficit at $35^{\circ} \mathrm{C}$ might be greater than modelled under controlled conditions with an unlimited food supply. Conversely, within a foraging and predation perspective, it is uncertain whether young blue tilapia have the opportunity of living at $T^{\circ}{ }_{\text {opt }}$ during the entire thermosensitive period. They usually inhabit shallow and calm inshore habitats (Fryer \& Iles, 1972; Ruwet et al., 1976; Philippart \& Ruwet, 1982), which serve as refuges and feeding grounds. Water temperature in these habitats is intimately dependent on air temperature and illumination, and it can be as high as, or higher than, masculinizing temperatures during daytime. Habitats with thermal regimes closer to $T_{\text {opt }}^{\circ}$ can be found further offshore, where water velocity can be faster (rivers) and food is usually less abundant than in riparian ecotones. Fish living at higher temperatures near the banks might also find more numerous refuges from predation than those living further offshore. It is not excluded either that blue tilapia may spend part of their time at $T^{\circ}{ }_{\text {opt }}$, part of their time at a masculinizing temperature, and the rest at a lower temperature without compromising masculinization, since phenotypic masculinization does not require the permanent ( $24 \mathrm{~h}$ a day) exposure to $T^{\circ}$ masc (Baras et al., 2000). As a corollary, whether living at a masculinizing temperature represents a major drawback in natural environments is uncertain, as it depends on food availability and predation pressure. Both can vary substantially between the river, floodplain and lake ecosystems colonized by blue tilapias, and are largely unknown.

Male tilapia species grow faster than sibling females from a young age (Rothbard et al., 1987; Baras \& Mélard, 1997), and this is seemingly the case for 


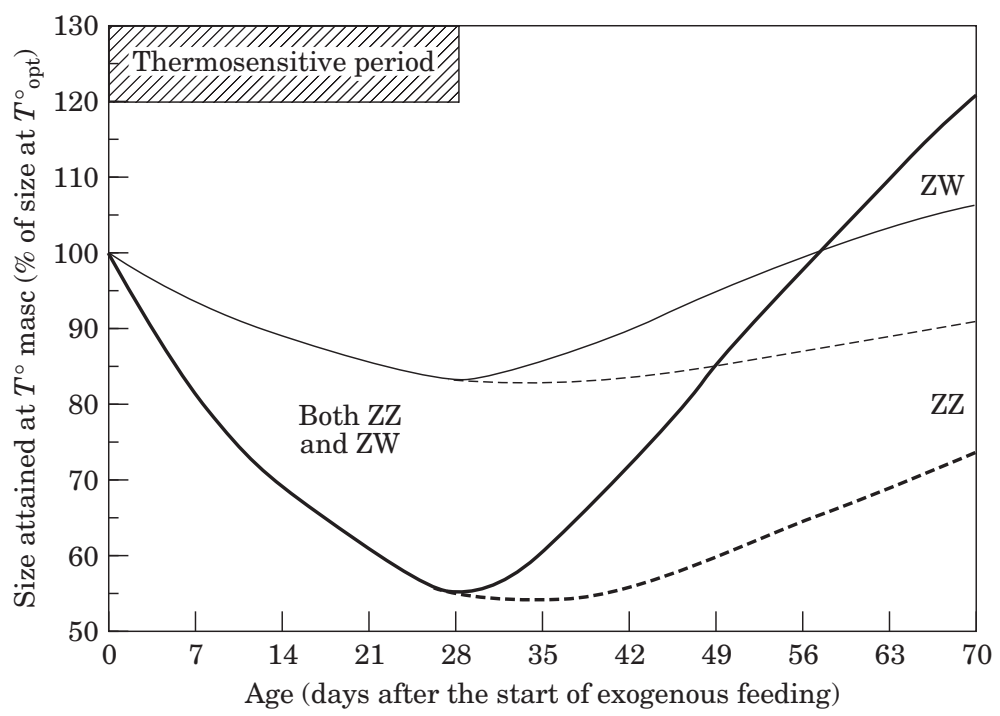

FIG. 3. Cost of living at a masculinizing temperature $\left(35^{\circ} \mathrm{C}\right)$ in juvenile blue tilapia. The vertical axis gives the cost as a proportion of the size attained by siblings living at $T^{\circ}$ opt throughout. ——, Body mass and - , total body length for ZW and - -, body mass and -- total body length for ZZ genotypes. $\mathrm{ZZ}$ fish gain no advantage from living initially at $T^{\circ}$ masc; the initial cost decreases progressively because growth is size-dependent. ZW fish initially pay the same cost as ZZ siblings, but the cost diminishes readily because of between sex-growth dimorphism. In theory, sex-reversed ZW fish catch up ZW siblings raised at $T^{\circ}$ opt throughout $c$. 8 weeks after the start of exogenous feeding ( 4 weeks after the end of the thermosensitive period). The thermosensitive period in blue tilapia is assumed to last for 4 weeks, by reference to previous studies (Desprez \& Mélard, 1998; Baras et al., 2000). Growth rates and body masses at $T^{\circ}$ opt and $35^{\circ} \mathrm{C}$ are obtained from the model in Table II. Total body length determined from the length $\left(L_{\mathrm{T}}\right)$ and mass $(M)$ relationship: $\log \left(L_{\mathrm{T}}\right)=0 \cdot 6333+0 \cdot 3126 \log M(\mathrm{E}$. Baras, unpubl. data). The dynamics of between-sex growth dimorphism is deduced from the model proposed by Baras \& Mélard (1997) for young Nile tilapia.

sex-reversed fishes too (Pandian \& Sheela, 1995). Genotypic females that are transformed into phenotypic males at warm temperatures might compensate for the initial growth deficit within no more than 8 weeks (Fig. 3). At an older age, they might have greater chances than non-reversed females of escaping predator attacks, making the importance of the potential growth deficit incurred during the thermosensitive period more uncertain and dependent on predation pressure. Finally, the hypothesis that the masculinizing temperature also decreases during the ontogeny of tilapias, making the potential growth deficit (if any) smaller than predicted on experimental grounds, cannot be ruled out.

In conclusion, this study suggests that the exposure of juvenile blue tilapia to warm, masculinizing temperatures is likely to induce an initial and temporary loss of fitness, the extent of which is extremely contextual, and uncertain in some circumstances. This suggests that there is no definite, permanent selection pressure upon TSD in blue tilapia, and probably in other oreochromines (Baras et al., 2001). This interpretation applies specifically to genotypically female individuals, while for genotypically male fish, the initial disadvantage would remain. Hence, and notwithstanding the issue of predation outlined above, the selection of warm temperatures during the early ontogeny might have different consequences for males and females. Whether blue tilapia have evolved a between-sex difference in $T^{\circ}$ opt is totally unknown, but tilapia species are 
certainly a good biological material for testing this hypothesis, since monosex male and female progenies can now be produced from breeders with altered genotypes and phenotypes (e.g. YY males in O. niloticus: Scott et al., 1989, ZZ females in O. aureus: Mélard 1995).

This study was supported by Electrabel s.a, and benefited from the support of a FIRST University Research Programme funded by the Ministry of New Technologies of the Walloon Region (D.G.T.R.E; ref. 3337-991/3908). E. Baras is a research associate of the Belgian F.N.R.S. A. Mpo'N'Tcha and H. Driouch were granted fellowships by the Belgian C.U.D. during their stay in Belgium.

\section{References}

Abucay, J. S., Mair, G. C., Skibinski, D. O. F. \& Beardmore, J. A. (1999). Environmental sex determination: the effect of temperature and salinity on sex ratio of Oreochromis niloticus L. Aquaculture 173, 219-234.

Baras, E. \& Mélard, C. (1997). Individual growth patterns of juvenile Nile tilapia Oreochromis niloticus (L.): Emergence and dynamics of sexual growth dimorphism. Northeast Regional Agricultural Service 106, 169-177.

Baras, E., Prignon, C., Gohoungo, G. \& Mélard, C. (2000). Phenotypic sex differentiation of blue tilapia under constant and fluctuating thermal regimes and its adaptive and evolutionary implications. Journal of Fish Biology 57, 210-223. doi/10.1006/ jfbi.2000.1298.

Baras, E., Jacobs, B. \& Mélard, C. (2001). Effect of water temperature on survival, growth and phenotypic sex of mixed (XX-XY) progenies of Nile tilapia Oreochromis niloticus. Aquaculture 192, 187-199.

Baroiller, J.-F., Chourrout, D., Fostier, A. \& Jalabert, B. (1995). Temperature and sex chromosomes govern sex ratios of the mouthbrooding cichlid fish Oreochromis niloticus. Journal of Experimental Zoology 273, 216-223.

Baroiller, J.-F., Fostier, A., Cauty, C., Rognon, X. \& Jalabert, B. (1996a). Significant effects of high temperatures on sex ratio of progenies from Oreochromis niloticus with sibling sex-reversed male broodstock. In Proceedings of the Third International Symposium on Tilapia in Aquaculture (Pullin, R. S. V., Lazard, J., Legendre, M., Amon Kothias, J. B. \& Pauly, D., eds). ICLARM Conference Proceedings 41, 333-343.

Baroiller, J.-F., Nakayama, I., Foresti, F. \& Chourrout, D. (1996b). Sex determination studies in two species of teleost fish, Oreochromis niloticus and Leporinus elongatus. Zoological Studies 35, 279-285.

Baroiller, J.-F., Clota, F. \& Géraz, E. (1996c). Temperature sex determination in two tilapias species, Oreochromis niloticus and the red tilapia (Red Florida strain): effect of high or low temperatures. In Proceedings of the Fifth International Symposium on the Reproductive Physiology of Fish (Goetz, F. \& Thomas, P., eds), pp. 158-160. Austin, TX: University of Austin.

Baroiller, J.-F., Guiguen, Y. \& Fostier, A. (1999). Endocrine and environmental aspects of sex differentiation in fish. Cellular and Molecular Life Sciences 55, 910-931.

Brett, J. R. (1979). Environmental factors and growth. In Fish Physiology, Vol. 8 (Hoar, W. S., Randall, D. J. \& Brett, J. R., eds), pp. 599-675. New York: Academic Press.

Buentello, J. A., Gatlin, D. M. III \& Neill, W. H. (2000). Effects of water temperature and dissolved oxygen content on daily feed consumption, feed utilization and growth of channel catfish (Ictalurus punctatus). Aquaculture 182, 339-352.

Conover, D. O. (1984). Adaptive significance of temperature dependent sex determination in a fish. American Naturalist 123, 298-313.

Conover, D. O. \& Heins, S. W. (1987a). Adaptive variation in environmental and genetic sex determination in a fish. Nature 326, 496-498. 
Conover, D. O. \& Heins, S. W. (1987b). The environmental and genetic components of sex ratio in Menidia menidia (Pisces: Atherinidae). Copeia 1987, 732-743.

Conover, D. O. \& Kynard, B. E. (1981). Environmental sex determinism: interaction of temperature and genotype in a fish. Science 213, 577-579.

Desprez, D. (1998). Etude de l'influence du génotype sexuel sur le déterminisme du sexe, la reproduction et la croissance chez le tilapia Oreochromis aureus (Pisces, Cichlidae) (Steindachner, 1864). PhD Thesis dissertation, University of Liège, Belgium.

Desprez, D. \& Mélard, C. (1998). Effect of ambient water temperature on sex determinism in the blue tilapia, Oreochromis aureus. Aquaculture 162, 79-84.

Elliott, J. M. (1975a). The growth rate of brown trout (Salmo trutta L.) fed on maximum rations. Journal of Animal Ecology 44, 805-821.

Elliott, J. M. (1975b). The growth rate of brown trout (Salmo trutta L.) fed on reduced rations. Journal of Animal Ecology 44, 823-842.

Farmer, G. J., Ashfield, D. \& Goff, T. R. (1983). A feeding guide for juvenile Atlantic salmon. Canadian Report of Fisheries and Aquatic Sciences 1718, 1-13.

Fonds, M. \& Saksena, V. P. (1977). The daily food intake of young soles (Solea solea L.) in relation to their size and the water temperature. Actes du Colloque du Centre National pour L'Exploitation des Oceans 4, 51-58.

Francis, R. C. (1984). The effects of bidirectional selection for social dominance on agonistic behaviour and sex ratios in the paradise fish (Macropodus opercularis). Behaviour 90, 25-45.

Fry, F. E. J. (1971). The effects of environmental factors on the physiology of fish. In Fish Physiology, Vol. 6 (Hoar, W. S. \& Randall, D. J., eds), pp. 1-98. New York: Academic Press.

Fryer, G. \& Iles, T. D. (1972). The Cichlid Fishes of the Great Lakes of Africa: their Biology and Evolution. Edinburgh: Oliver and Boyd.

Guerrero, R. D. \& Shelton, W. L. (1974). An aceto-carmine squash method for sexing juvenile fishes. Progressive Fish-Culturist 36, 56.

Hogendoorn, H., Jansen, J. A. J., Koops, W. J., Machiels, M. A. M., Ewijk, P. H. van \& Hess, J. P. van (1983). Growth and production of the African catfish, Clarias lazera (C \& V.). II. Effects of body weight, temperature and feeding level in intensive tank culture. Aquaculture 34, 265-285.

Hostache, G., Pascal, M. \& Tessier, C. (1995). Influence de la température d'incubation sur le rapport mâle:femelle chez l'atipa, Hoplosternum littorale Hancock (1828). Canadian Journal of Zoology 73, 1239-1246.

Huisman, E. A., Klein Bretler, J. G. P., Vismans, M. M. \& Kanis, E. (1979). Retention of energy, protein, fat and ash in growing carp (Cyprinus carpio) under different feeding and temperature regimes. In Finfish Nutrition and Fishfeed Technology, Vol. I (Halver, J. E. \& Tiews, K., eds), pp. 175-188. Berlin: Hennemann.

Jobling, M. (1981). Temperature tolerance and the final preferendum - a rapid method for the assessment of optimum growth temperatures. Journal of Fish Biology 19, 439-455.

Jobling, M. (1983). Growth studies with fish-overcoming the problems of size variation. Journal of Fish Biology 22, 153-157.

Jobling, M. (1994). Fish Bioenergetics. London: Chapman \& Hall.

Jobling, M. (1997). Temperature and growth: modulation of growth rate via temperature change. In Global Warming: Implications for Freshwater and Marine Fish (Wood, C. M. \& McDonald, D. G., eds), pp. 225-253. Cambridge: Cambridge University Press.

Kestemont, P. \& Baras, E. (2001). Environmental factors and feed intake in fish. In Food Intake in Fish (Houlihan, D., Boujard, T. \& Jobling, M., eds), pp. 131-156. Oxford: Blackwell Science Ltd.

Kitchell, J. F., Stewart, D. J. \& Weininger, D. (1977). Applications of a bioenergetics model to yellow perch (Perca flavescens) and walleye (Stizostedion vitreum vitreum). Journal of the Fisheries Research Board of Canada 34, 1922-1935. 
Koskela, J., Pirhonen, J. \& Jobling, M. (1997). Feed intake, growth rate and body composition of juvenile Baltic salmon exposed to different constant temperatures. Aquaculture International 5, 351-360.

Mélard, C. (1986). Les bases biologiques de l'élevage du tilapia du Nil. Cahiers d'Éthologie appliquée 6, 1-224.

Mélard, C. (1995). Production of high percentage male offspring with 17 a-ethynylestradiol sex reversed Oreochromis aureus: I. Estrogen sex-reversal and production of F2 pseudofemales. Aquaculture 130, 25-34.

Mironova, N. V. (1976). Changes in the energy balance of Tilapia mossambica in relation to temperature and ration size. Journal of Ichthyology 6, 120-129.

Nomura, T., Arai, K., Hayashi, T. \& Suzuki, R. (1998). Effect of temperature on sex ratios of normal and gynogenetic diploid loach. Fisheries Science 64, 753-758.

Pandian, T. J. \& Sheela, S. G. (1995). Hormonal induction of sex reversal in fish. Aquaculture 138, 1-22.

Pauly, D. (1981). The relationship between gill surface area and growth performance in fish: a generalization of von Bertalanffy's theory of growth. Meereforschung 28, 251-282.

Pavlidis, M., Koumoundouros, G., Sterioti, A., Somarakis, S., Divanach, P. \& Kentouri, M. (2000). Evidence of temperature-dependent sex determination in the European sea bass (Dicentrarchus labrax L.). Journal of Experimental Zoology 287, 225-232.

Philippart, J.-C. \& Ruwet, J.-C. (1982). Ecology and distribution of tilapias. In The Biology and Culture of Tilapias (Pullin, R. S. V. \& Lowe McConnell, R. H., eds). ICLARM Conference Proceedings 7, 5-59.

Römer, U. \& Beisenherz, W. (1996). Environmental determination of sex in Apistogramma (Cichlidae) and two other freshwater fishes. Journal of Fish Biology 48, 714-725. doi/10.1006/jfbi.1996.0072.

Rothbard, S., Moav, B. \& Yaron, Z. (1987). Changes in steroid concentrations during the ontogenesis in tilapia. Aquaculture 61, 59-74.

Rubin, D. A. (1985). Effect of $\mathrm{pH}$ on sex ratio in cichlids and a poeciliid (Teleostei). Copeia 1985, 233-235.

Ruwet, J.-C. (1968). Familial behaviour of Tilapia and its implications. Nature 217, 977.

Ruwet, J.-C., Voss, J., Hanon, L. \& Micha, J.-C. (1976). Biologie et élevage du tilapia. In Symposium on Aquaculture in Africa. CIFA Technical Paper 4 (Suppl.1), 332-364.

Ruyung, S. \& Yushu, Z. (1982). Influence of water temperature on growth of Tilapia. Acta Ecologica Sinica 2, 181-188.

Scott, A. G., Penman, D. J., Beardmore, J. A. \& Skibinski, D. O. F. (1989). The 'YY' supermale in Oreochromis niloticus (L.) and its potential in aquaculture. Aquaculture 78, 237-251.

Schultz, R. J. (1993). Genetic regulation of temperature-mediated sex ratios in the live-bearing fish Poecilopus lucida. Copeia 1993, 1148-1151.

Strüssmann, C. A. \& Patino, R. (1999). Sex determination, environmental. In Encyclopedia of Reproduction, Vol. 4 (Knobil, E. \& Neill, J. D., eds), pp. 402-409. New York: Academic Press.

Strüssmann, C. A., Calsina Cota, J. C., Phonlor, G., Higuchi, H. \& Takashima, F. (1996a). Temperature effects on sex differentiation of two South American atherinids, Odontesthes argentinensis and Patagonina hatcheri. Environmental Biology of Fishes 47, 143-154.

Strüssmann, C. A., Moriyama, S., Hanke, E. F., Calsina Cota, J. C. \& Takashima, F. (1996b). Evidence of thermolabile sex determination in pejerrey. Journal of Fish Biology 48, 643-651. doi/10.1006/jfbi.1996.0064.

Warner, R. R. (1988). Sex change in fishes: hypotheses, evidences and objections. Environmental Biology of Fishes 22, 81-90.

Wootton, R. J. (1990). Ecology of Teleost Fishes. London: Chapman \& Hall. 